\title{
PERTUMBUHAN DAN PRODUKSI HIJAUAN LEGUM POHON Indigofera zollingeriana SEBAGAI HIJAUAN PAKAN STRATEGIS DI PULAU LOMBOK
}

\author{
Yusuf Akhyar Sutaryono*, Harjono, Mastur, dan Ryan Aryadin Putra \\ Fakultas Peternakan Universitas Mataram \\ *Coresponding e-mail: ysf25@yahoo.com
}

\begin{abstract}
ABSTRAK
Penelitian bertujuan untuk mengetahui pertumbuhan dan produksi Indigofera dengan interval pemotongan berbeda yang dibudidayakan di Pulau Lombok. Penelitian dirancang dengan rancangan acak kelompok (RAK) dengan 3 kelompok interval pemotongan yaitu 30, 45 dan 6o hari setelah potong paksa. Pemotongan paksa dilakukan pada ketinggian $50 \mathrm{~cm}$ di atas tanah pada 11 minggu setelah tanam. Hasil penelitian menunjukkan bahwa pertumbuhan Indigofera 30, 45 dan 60 hari setelah pemotongan berturut-turut adalah 89,2, 120,o dan 161,0 cm. Sedangkan laju pertumbuhan tanaman sebesar 7,96, 10,47 dan 13,89 cm/minggu. Pembentukan percabangan pada minggu pertama sebanyak 5,0 cabang/pohon dan tumbuh signifikan menjadi 25,0 cabang/pohon setelah 4 minggu. Pembentukan cabang mencapai 40 cabang pada 60 hari setelah pemotongan paksa. Kondisi ini menunjukkan bahwa tanaman tetap tumbuh dengan cepat dan tepat meskipun tanaman ditebang. Produksi Indigofera tertinggi diperoleh pada interval pemotongan 60 hari $(864,40$ gram/pohon) diikuti dengan peningkatan bahan kering dan bahan organik, tetapi kadar protein menurun secara signifikan. Disimpulkan bahwa Indigofera merupakan tanaman potensial yang dapat dikembangkan dan dimanfaatkan sebagai sumber pakan ternak andalan di Pulau Lombok.
\end{abstract}

Kata kunci: produksi hijauan, Indigofera zollingeriana, interval pemotongan, pertumbuhan

\section{GROWTH AND PRODUCTION OF TREE LEGUM Indigofera zollingeriana AS A STRATEGIC FORAGE IN LOMBOK ISLAND}

\begin{abstract}
The study was aimed to determine the growth and production of Indigofera with different cutting intervals cultivated in Lombok Island. The study was designed with Completely Randomized Block Design with 3 blocks of cutting intervals i.e. of 30,45 and 60 days after forced cut. The forced cut was applied at 50 $\mathrm{cm}$ above ground at 11 weeks after planting. The result showed that the growth of Indigofera 30, 45 and 60 days after cutting were 89.2, 120.0 and $161.0 \mathrm{~cm}$ concecutively. Meanwhile the growth rate of the plants were 7.96, 10.47 and $13.89 \mathrm{~cm} /$ week. The branching formation in first week were 5.0 branches/tree and growing significantly to 25.0 branches/tree after 4 weeks. The branches formation achieved 40 branches at 60 days after forced cut. This condition showed that the plant keep growing fastly and rigourisly although the plants were cut. The highest production of Indigofera was obtained at the cutting interval of 60 days (864.40 gram/tree; $\mathrm{P}<0.05$ ) followed by increasing dry and organic matter, but the protein content decreased significantly $(\mathrm{P}<0.05)$. It is concluded that Indigofera is potential plant that could be develop and used as reliable cattle feed sources in Lombok Island.
\end{abstract}

Keywords: forage production, Indigofera zollingeriana, cutting interval, growth

\section{PENDAHULUAN}

Ternak ruminansia di Indonesia memiliki peranan yang sangat penting dalam memenuhi kebutuhan daging nasional. Kebutuhan daging nasional sebagian besar merupakan kontribusi dari peternakan rakyat dan kekurangannya dipasok impor. Permasalahan yang dihadapi peternak saat ini adalah rendahnya produktivitas ternak sebagai dampak dari rendahnya kualitas dan kuantitas hijauan pakan. Rendahnya produktivitas ternak potong disebabkan karena status nutrisi dan suplai hijauan sepanjang tahun yang rendah terutama pada musim kemarau, khususnya di daerah kering wilayah Timur Indonesia (Bamualim, 2009). Terbatasnya pasokan hijauan pakan selama musim kemarau bukan hanya terjadi di Indonesia bagian Timur, namun di wilayah lain juga mengalami hal serupa. Antara lain hal ini disebabkan karena petani hanya mengandalkan hijauan pakan lokal yang terdapat di sekitar pekarangan, perkebunan, hutan 
dan ladang.

Ketersediaan pakan merupakan kendala utama yang sering dihadapi oleh peternak sapi dan kerbau pada umumnya, hal ini sangat dirasakan oleh peternak terutama pada musim kemarau. Hal ini juga semakin diperparah dengan semakin menyempitnya areal penggembalaan ternak dan tidak adanya lahan yang dapat dikembangkan untuk menanam tanaman pakan. Untuk mengatasi keterbatasan pakan terutama musim kemarau diperlukan altenatif lainnya untuk menyediakan hijauan pakan ternak selain rumput. Tanaman legum pohon adalah salah satu pilihan yang sangat tepat untuk mengatasi masalah ini. Indigofera zollingeriana (I. zollingeriana) adalah salah satu legum pohon yang sangat potensial untuk dikembangkan sebagai sumber pakan hijauan mengatasi kekurangan pakan dimsim kemarau.

Legum pohon I. zollingeriana sangat disukai oleh ternak ruminansia dan memiliki kandungan protein yang sangat tinggi, mencapai 27\% (Abdullah, 2010). Tanaman ini sudah mulai dikembangkan dan menarik minat kalangan peternak sebagai sumber protein bagi ternak mereka. Tanaman ini baru mulai diperkenalkan dan dikembangkan di Pulau Lombok. Informasi tentang pertumbuhan dan kecocokan tanaman ini di Pulau Lombok masih sangat terbatas demikian pula dengan nilai nutrisi serta kualitasnya sebagai pakan ternak. Tujuan khusus dari penelitian ini adalah untuk mengetahui pertumbuhan dan produktivitas tanaman legum pohon I. zollingeriana serta potensinya sebagai sumber pakan ternak ruminansia di Pulau Lombok.

\section{MATERI DAN METODE}

Benih I. zollingeriana yang digunakan dalam penelitian ini diperoleh dari Balai Hijauan Pakan Serading Sumbawa. Biji Indigofera dilakukan persemaian terlebih dahulu pada bedengan untuk menumbuhkan bibit. Setelah benih tumbuh dengan baik dan siap untuk dipindahkan kemudian tanaman akan dipindahkan ke bedengan yang sudah disiapkan untuk perawatan lanjutan dan pengambilan data. Pengelompokan tanaman didasarkan pada perlakuan yang diterapkan pada penanaman I. zollingeriana. Perlakuan untuk penanaman adalah perbedaan periode panen untuk tiap kelompok tanaman. Periode pemotongan tanaman adalah 30 hari ( 1 bulan), 45 hari (1,5 bulan) dan 60 hari (2 bulan).

Parameter pengujian aspek agronomi tanaman $I$. zollingeriana meliputi pertumbuhan dan produksi hijauan tanaman I. zollingeriana. Untuk mengetahui kualitas tanaman $I$. zollingeriana sebagai hijauan pakan ternak dilakukan analisis kandungan bahan Kering (BK), bahan organik (BO) dan kandungan protein kasar (PK) serta pengujian nilai kecernaannya melalui analisis kecernaan secara in vitro. Analisis proksimat dilakukan dengan mengikuti prosedur AOAC (2005) dan pengujian kecernaan bahan kering (KcBK) dan kecernaan bahan organik (KcBO) dilakukan dengan metode yang dikembangkan oleh Tilley and Terry (1967). Data yang diperoleh dianalisis dengan menggunakan analisis sidik ragam (ANOVA) menggunakan paket SPSS for Windows versi 22.

\section{HASIL DAN PEMBAHASAN}

\section{Kondisi Pertumbuhan Awal I. zollingeriana}

Tanaman Indigofera yang ditanam ditanah regosol dengn iklim basah menghasilkan pertumbuhan yang subur dan bertumbuh dengan baik. Tanaman terlihat hijau segar dengan daun dan batang yang hijau segar dan tumbuh dengan cepat. Tabel 1 menunjukkan data tinggi tanaman dan jumlah cabang yang terbentuk selama pertumbuhan tanaman Indigofera selama 11 minggu. Dari data terlihat bahwa tanaman Indigofera mencapai tinggi 164,22 cm saat mencapai umur 11 minggu dengan jumlah cabang mencapai rata-rata sebanyak 23 buah cabang

Tabel 1. Tinggi Tanaman dan Jumlah Cabang Tanaman $I$. zollingeriana dalam 11 Minggu

\begin{tabular}{ccc}
\hline $\begin{array}{c}\text { Umur } \\
(\text { minggu })\end{array}$ & Tinggi tanaman $(\mathrm{cm})$ & $\begin{array}{c}\text { Jumlah cabang } \\
\text { (buah/pohon) }\end{array}$ \\
\hline 1 & $12,61 \pm 3,80$ & 0 \\
2 & $16,60 \pm 4,60$ & $1,0 \pm 1,79$ \\
3 & $20,86 \pm 6,04$ & $2,0 \pm 2,23$ \\
4 & $28,20 \pm 8,34$ & $3,0 \pm 2,78$ \\
5 & $38,16 \pm 11,50$ & $4,0 \pm 3,24$ \\
6 & $52,42 \pm 16,53$ & $6,0 \pm 4,09$ \\
7 & $70,62 \pm 21,72$ & $9,0 \pm 4,18$ \\
8 & $89,20 \pm 27,01$ & $11,0 \pm 4,56$ \\
9 & $106,80 \pm 29,44$ & $13,0 \pm 4,86$ \\
10 & $125,53 \pm 31,74$ & $15,0 \pm 4,72$ \\
11 & $164,22 \pm 37,72$ & $23,0 \pm 7,55$ \\
\hline
\end{tabular}

Pertambahan jumlah cabang tanaman terjadi segera 1 minggu setelah penanaman dengan tumbuhnya cabang baru sebanyak 1 - 6 buah cabang sampai dengan minggu ke 6 , kemudian pertumbuhan cabang baru meningkat tajam pada minggu ke-7 sampai dengan minggu ke-11 setelah penanaman dengan pertumbuhan $9-23$ buah cabang baru. Meningkat tajamnya pertumbuhan cabang tanaman Indigofera pada ke-7 sampai dengan minggu ke-11 setelah penanaman disebabkan karena pada rentang umur tersebut sudah cukup banyak tersedia cadangan karbohidrat yang terdapat pada batang dan akar dan segera digunakan semaksimal mungkin untuk menumbuhkan tunas-tunas percabangan baru, sehingga pada gilirannya akan meningkatkan jumlah percabangan serta menghasilkan produksi biomasa 
Tabel 2. Rerata Tinggi, Pertambahan Tinggi, Jumlah Cabang, Pertambahan Jumlah Cabang, Kandungan Bahan Kering, dan Produksi Bahan Kering I. zollingeriana pada Umur Pemotongan Berbeda

\begin{tabular}{lcc}
\hline \multicolumn{1}{c}{ Variabel } & \multicolumn{2}{c}{ Umur pemotongan } \\
\cline { 2 - 3 } Tinggi tanaman (cm) & 30 hari & 45 hari \\
Pertambahan tinggi tanaman (cm/minggu) & $74,40^{\mathrm{a}} \pm 7,34$ & $63,23^{\mathrm{b}} \pm 4,14$ \\
Jumlah cabang (buah) & $7,96^{\mathrm{a}} \pm 0,76$ & $16,13^{\mathrm{c}} \pm 7,70$ \\
Pertambahan jumlah cabang (batang/minggu) & $25,33^{\mathrm{b}} \pm 2, \mathrm{oo}$ & 1,54 \\
\hline
\end{tabular}

a,b,c Superskrip yang berbeda pada baris yang sama menujukkan perbedaan yang nyata $(\mathrm{P}<0,05)$

tanaman lebih tinggi. Ngo van Man et al. (1995) menyatakan bahwa laju pertumbuhan Indigofera $s p$. pada tanah masam dengan $\mathrm{pH} 4,5-5,0$, lebih cepat sebesar 9,8 cm per dua minggu, dari pada Leucaena $s p$. sebesar $7,8 \mathrm{~cm}$ per dua minggu.

\section{Tinggi Total Tanaman dan Pertambahan Tinggi Tanaman I. zollingeriana}

Tinggi tanaman saat potong paksa (pemotongan pertama) adalah $50 \mathrm{~cm}$ dari atas permukaan tanah. Selanjutnya tanaman dibiarkan tumbuh selama 30 hari, 45 hari dan 60 hari sebelum kemudian dilakukan pemotongan yang kedua.

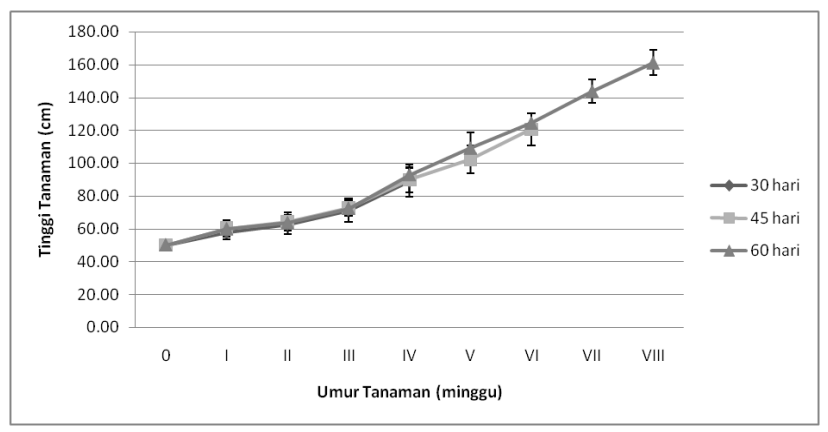

Gambar 1. Pertumbuhan kembali Indigofera selama 30, 45 dan 60 hari setelah potong paksa

Gambar 1 menunjukkan pertumbuhan kembali tanaman Indigofera selama 30 hari setelah potong paksa adalah bertambah sekitar $49 \mathrm{~cm}$ menjadi 89,2 $\mathrm{cm}$. Pertumbuhan kembali selama 45 hari bertambah $45 \mathrm{~cm}$ menjadi $120 \mathrm{~cm}$, pertumbuhan kembali 60 hari setelah potong paksa bertambah $110 \mathrm{~cm}$ menjadi 161 $\mathrm{cm}$. Cukup tingginya pertumbuhan kembali selama 30, 45, dan 60 hari setelah potong paksa menunjukkan bahwa meskipun tanaman $I$. zollingeriana dipotong namun pertumbuhan kembalinya tetap sangat baik. Tanaman I. zollingeriana mencapai tinggi semula sebelum potong paksa dalam waktu 60 hari (2 bulan). Dengan kondisi ini maka dapat diartikan bahwa tanaman indigofera dapat dipotong kembali paling lambat dalam waktu 2 bulan. Wilson dan Rowe (2008) menyatakan bahwa Indigofera $s p$. adalah sejenis leguminosa pohon yang memiliki ketinggian 2-3 meter bahkan lebih dan dapat dipa- nen pada umur antara 6-8 bulan dengan produksi biomasa serta kandungan nutrisi yang tinggi pada kondisi yang normal dan suboptimal. Lebih lanjut Sirait et al. (2009) menyatakan Indigofera zollingeriana merupakan leguminosa pohon yang memiliki pertumbuhan yang cepat dengan tinggi rata-rata 418 cm pada umur 7 bulan.

Tabel 2 menunjukkan tinggi tanaman nyata dipengaruhi oleh umur pemotongan $(\mathrm{P}<0,05)$. Tanaman I. zollingeriana setelah 30 hari dilakukan potong paksa menghasilkan tinggi tanaman sebesar 74,40 $\mathrm{cm}$ dan meningkat pada umur pemotongan 45 dan 60 hari yang menghasilkan tinggi tanaman beturut-turut sebesar 63,23 cm dan 161,13 cm $(\mathrm{P}<0,05)$. Hal serupa juga terjadi pada tinggi tanaman yang diukur per minggu. Kondisi ini berarti tanaman $I$. zollingeriana secara linear bertambah tingginya sesuai dengan durasi waktu umur pemotongan. Lebih tinggi dan berbedanya tinggi tanaman pada umur pemotongan 60 hari diduga disebabkan oleh umur pemotongan yang lebih lama sehingga lebih memberikan kesempatan bagi tanaman I. zollingeriana untuk melakukan pertumbuhan kembali secara akumulatif. Sesuai dengan Tong et al. (2003) yang menyatakan bahwa tanaman akan lebih memiliki kesempatan yang lebih panjang untuk mengembangkan perakaran serta mengakumulasi hasil fotosintesis ke dalam jaringan meristem akar dan tajuk tanaman dengan memperpanjang interval pemotongan.

Pemotongan tanaman dalam interval yang pendek menyebabkan pertumbuhan kembali akan semakin lambat karena tanaman tidak memiliki kesempatan yang cukup untuk berasimilasi sehingga sangat mempengaruhi pertumbuhan berikutnya (Rahman, 2002). Lebih lanjut, Crowder dan Cheda (1982) menyatakan bahwa interval pemotongan pada tanaman berpengaruh terhadap produksi hijauan, nilai nutrisi, kemampuan tanaman untuk tumbuh kembali, komposisi botani dan ketahanan spesies tanaman. Setelah pemotongan, adaptasi tanaman sangat bergantung terhadap respon morfologi dan fisiologinya. Kemampuan tanaman untuk berfotosintesis guna memenuhi kebutuhannya setelah pemotongan sangat tergantung dari kemampuan tanaman tersebut menggunakan karbon dan nitrogen yang tersedia (Kavanova dan Gloser, 2004). 
Tabel 3. Produksi Hijauan Tanaman Indigofera pada Umur Pemotongan 30, 45, dan 6o Hari

\begin{tabular}{lccc}
\hline \multirow{2}{*}{ Variabel } & \multicolumn{3}{c}{ Umur pemangkasan } \\
\cline { 2 - 4 } & 30 hari & 45 hari & 60 hari \\
\hline Produksi segar (g/pohon) & $396,53^{\mathrm{a}} \pm 74,8$ & $468,87^{\mathrm{a}} \pm 29,9$ & $864,40^{\mathrm{b}} \pm 33,0$ \\
Produksi segar (ton/ha) & $1,98^{\mathrm{a}} \pm 0,43$ & $2,34^{\mathrm{a}} \pm 0,28$ & $4,32^{\mathrm{b}} \pm 0,25$ \\
Produksi bahan kering (g/pohon/2 bulan pemotongan) & $69,12^{\mathrm{a}} \pm 19,81$ & $94,78^{\mathrm{b}} \pm 27,44$ & $241,92^{\mathrm{c}} \pm 50,49$ \\
Produksi bahan kering (ton/ha/2 bulan pemotongan) & $0,35^{\mathrm{a}} \pm 0,10$ & $0,63^{\mathrm{b}} \pm 0,18$ & $1,21^{\mathrm{c}} \pm 0,25$ \\
\hline
\end{tabular}

$\mathrm{a}, \mathrm{b}, \mathrm{c}$ Superskrip yang berbeda pada baris yang menujukkan perbedaan nyata $(\mathrm{p}<0,05)$

Jumlah Total Cabang dan Pertambahan Jumlah Tunas Cabang Tanaman I. zollingeriana

Jumlah total cabang secara nyata dipengaruhi oleh umur pemotongan. Pemotongan umur 60 hari $(40,47$ cabang) nyata lebih tinggi dibanding dengan jumlah total cabang yang dihasilkan oleh pemotongan umur 30 hari (25,33 cabang) dan pemotongan 45 umur hari $(17,10$ cabang) (Tabel 2; $\mathrm{P}<0,05)$. Pemotongan umur 45 hari meskipun jumlah cabang yang paling rendah diantara perlakuan namun analisis variansi menunjukkan tidak adanya perbedaan dengan jumlah cabang pada perlakuan pemotongan umur 30 hari. Lebih banyaknya jumlah total cabang pada perlakuan umur pemotongan 60 hari disebabkan oleh alokasi waktu yang lebih panjang sehingga lebih memberikan peluang bagi tanaman I. zollingeriana untuk lebih banyak menyimpan dan memanfaatkan cadangan karbohidrat terutama pada bagian akarnya untuk menumbuhkan lebih banyak tunas-tunas percabangan baru. Hal tersebut juga yang menyebabkan meskipun secara rerata perlakuan pemotongan umur 60 hari nyata lebih tinggi jumlah cabang yang dihasilkan namun pertambahan jumlah tunas cabang jika dihitung per minggu menunjukkan nilai rerata yang nyata lebih rendah dibanding dengan nilai rerata perlakuan pemotongan umur 30 dan 45 hari $(5,06$ vs 6,30, 6,28; berturutan; $\mathrm{P}<0,05$ ). Herdiawan dan Sutepi (2012) melaporkan bahwa secara keseluruhan pemotongan dengan interval 90 hari menghasilkan produksi biomasa lebih tinggi dibandingkan dengan interval pemotongan 60 hari. Produksi biomassa yang lebih tinggi dalam penelitiannya tersebut tentu juga mencakup jumlah batang yang dihasilkan.

Laju fotosintesis tanaman akan mengalami penurunan karena aktivitas pemotongan. Tanaman akan memanfaatkan hasil fotosintesis untuk disimpan pada jaringan lain seperti jaringan meristem pucuk atau akar, sehingga pertumbuhan akar serta percabangan tanaman meningkat, dan pada gilirannya akan diikuti oleh produksi biomas yang tinggi (Kertulis, 2001). Pertumbuhan tunas-tunas baru energi yang digunakan berasal dari cadangan karbohidrat yang terdapat pada batang dan akar, dengan demikian proses produksi tunas baru menjadi lebih cepat setelah pemotongan, yang pada akhirnya bermuara pada meningkatnya produksi biomasa tanaman. Perlakuan pemotongan memberikan pengaruh yang nyata terhadap penurunan proses transpirasi tanaman pada daun, sehingga cekaman kekeringan yang dialami tanaman sedikit berkurang (Herdiawan dan Sutepi, 2012).

\section{Produksi Hijauan Tanaman Indigofera}

Produksi hijauan segar yang dihasilkan 30 hari setelah potong rata-rata 396,53 $\mathrm{g} /$ pohon dan semakin meningkat dengan bertambahnya umur pemotongan. Pemotongan 45 hari setelah potong paksa menghasilkan rata-rata 468,87 g/pohon dan pemotongan setelah 60 hari menghasilkan hijauan segar sebesar 864,40 g/pohon. Produksi hijauan pemotongan umur 30 hari tidak berbeda nyata dengan produksi hijauan umur 45 hari, namun menunjukkan perberbedaan yang nyata dengan umur pemotongan 60 hari ( $\mathrm{P}<0,05$; Tabel 3).

Tidak berbedanya produksi hijauan segar pada pemotongan 30 dan 45 hari diduga disebabkan oleh produksi biomassa berupa daun dan batang pada umur tersebut masih dalam kondisi normal. Berbeda halnya dengan interval pemotongan 60 hari yang memberikan respon yang berbeda yakni menghasilkan produksi segar tertinggi, kemungkinan disebabkan oleh interval pemotongan yang lebih panjang akan memberikan kesempatan bagi tanaman untuk menyimpan dan memanfaatkan fotosintat untuk pertumbuhan percabangan, tunas, dan perakaran yang baru, supaya proses pertumbuhan kembali (regrowth) dari tanaman tersebut tidak terganggu. Hasil penelitian ini sejalan dengan hasil dari penelitian Herdiawan dan Sutedi (2012) yang menunjukkan bahwa pada interval pemotongan 60 dan 90 hari menghasilkan produksi biomasa yang berbeda yakni berturut-turut sebesar 235,25 g/pot dan 334,68 g/pot.

\section{Kandungan Nutrien dan Kecernaan}

Kandungan bahan kering (BK) I. zollingeriana selengkapnya disajikan pada Tabel 2. Kandungan bahan kering (BK) dari pertumbuhan kembali selaras dengan produksi hijauan segarnya. Produksi bahan kering Indigofera rata-rata sebesar 17,29\% pada umur 30 hari, 20,30\% pada umur 45 hari dan $27,80 \%$. Kandungan BK terus menunjukkan peningkatan seiring dengan bertambahnya umur pemotong- 
Tabel 4. Kandungan Bahan Kering (BK), Bahan Organik (BO), Protein Kasar (PK), Kecernaan Bahan Kering (KcBK) dan Kecernaan Bahan Organik (KcBO) Tanaman Indigofera pada Umur Pemotongan 30, 45, dan 6o Hari

\begin{tabular}{|c|c|c|c|}
\hline \multirow{2}{*}{ Variabel } & \multicolumn{3}{|c|}{ Umur pemangkasan } \\
\hline & 30 hari & 45 hari & 60 hari \\
\hline Bahan kering (\%) & $17,29^{\mathrm{a}}$ & $20,30^{b}$ & $27,80^{c}$ \\
\hline Bahan organik (\%) & $87,15^{\mathrm{a}}$ & $87,15^{\mathrm{a}}$ & $92,03^{b}$ \\
\hline Protein kasar (\%) & $21,17^{\mathrm{c}}$ & $20,26^{b}$ & $18,94^{\mathrm{a}}$ \\
\hline Kecernaan bahan kering (\%) & $67,51^{\mathrm{c}}$ & $64,21^{\mathrm{b}}$ & $58,49^{\mathrm{a}}$ \\
\hline Kecernaan bahan organik (\%) & $73,34^{\mathrm{c}}$ & $69,30^{\mathrm{b}}$ & $63,98^{\mathrm{a}}$ \\
\hline
\end{tabular}

a,b,c Superskrip yang berbeda pada baris yang menujukkan perbedaan nyata $(\mathrm{p}<0,05)$

an. Hal serupa juga terjadi dengan kandungan bahan organik (BO). Kondisi ini bermakna bahwa semakin tua umur tanaman sewaktu dilakukan pemangkasan maka akan semakin tinggi produksi bahan keringnya $(\mathrm{P}<0,05)$. Meningkatnya kandungan $\mathrm{BK}$ seiring dengn bertambahnya umur pemotongan disebabkan setelah dilakukan pemangkasan pertama (pangkas paksa) sampai dengan dilakukan pemangkasan pada umur 60 hari, tanaman Indigofera menggunakan cadangan karbohidrat yang terdapat pada akar dan batang untuk dirombak menjadi energi bagi pertumbuhan tunas-tunas baru, sehingga memungkinkan tanaman tersebut untuk dengan cepat berproduksi menghasilkan tunas-tunas tanaman yang baru dan menghasilkan produksi bahan kering yang tinggi, dalam penelitian ini kondisi tersebut ditunjukkan oleh tingginya jumlah percabangan pada interval pemotongan 60 hari.

Selain itu, umur tanaman (lama durasi waktu pemangkasan) juga memiliki korelasi dengan kandungan bahan kering, hubungan tersebut terutama dengan kandungan air dalam batang dan daun tanaman. Semakin tua umur tanaman maka semakin rendah kandungan air sehingga memberikan proporsi meningkatnya kandungan bahan kering, hal ini sesuai dengan pernyataan Beever et al. (2000) bahwa semakin tua tanaman maka akan lebih sedikit kandungan airnya. Lebih lanjut Givens et al. (2000) menyatakan bahwa semakin tinggi umur pemotongan maka komponen dinding sel suatu hijauan akan semakin tinggi. Komponen dinding sel yang semakin tinggi mengakibatkan kandungan bahan kering juga semakin tinggi asumsi meningkatnya bahan kering karena dinding sel, dibuktikan dengan menurunnya kandungan protein kasar.

Kandungan protein kasar adalah 21,17\%, 20,26\% dan 18,94\% masing-masing untuk pemotongan umur 30 hari, 45 hari, dan 60 hari (Tabel 3). Kandungan protein kasar Indigofera semakin menurun dengan semakin meningkatnya umur pemotongan $(\mathrm{P}<0,05)$. Hasil ini selaras dengan Tarigan (2009) menyebutkan bahwa kandungan protein kasar (PK), kalsium (Ca) dan fosfor (P) semakin menurun tapi sebaliknya kandungan bahan organik, NDF, ADF semakin tinggi dengan meningkatnya interval pemotongan. Menurunnya kandungan protein kasar ini disebabkan oleh meningkatnya umur pemotongan sehingga memungkinkan terjadinya penurunan rasio daun dan batang. Shehu et al. (2001) menyatakan bahwa kualitas legum pohon dipengaruhi oleh rasio daun dan batang tanaman. Kandungan protein kasar tanaman Indigofera pada penelitian ini lebih rendah dari kandungan protein kasar Indogofera yang dilaporkan oleh Tjelele (2006) yakni berkisar antara 24,61\% $26,10 \%$. Perbedaan kandungan protein kasar tersebut diduga disebabkan oleh perbedaan kondisi biotik dan abiotik lokasi penelitian.

Tingginya kandungan protein kasar pada pemotongan kembali umur 30 hari disebabkan oleh umur tanaman relatif lebih muda dibanding dengan umur pemotongan 45 dan 60 hari, sehingga dinding sel belum mengandung bahan selulosa dan hemiselulosa yang tinggi yang berarti bahwa kandungan NDF dan ADF-nya cenderung masih rendah. Kondisi sebaliknya terjadi pada umur pemotongan kembali 45 dan 60 hari, dimana kandungan serat (terutama NDF dan ADF) telah dominan terbentuk sehingga menyebabkan porsi kandungan protein kasarnya menurun. Beever et al. (2000) menyatakan bahwa semakin tua umur tanaman menyebabkan proporsi dinding sel lebih tinggi dibanding isi sel.

Data pada Tabel 4 menunjukkan kecernaan bahan kering (KcBK) berturut-turut adalah sebesar $67,51 \%$, $64,21 \%$ dan $58,49 \%$ dan kecernaan bahan organik (KcBO) berturut-turut sebesar 73,34\%, 69,30\%, dan $63,98 \%$ untuk umur pemotongan 30 hari, 45 hari, dan 60 hari. Hasil KcBK dan KcBO pada penelitian ini termasuk memiliki kecernaan yang tinggi berkisar antara $58,49 \%-67,51 \%$ dan $63,98 \%-73,35 \%$. Nilai kecernaan ini hampir sama dengan hasil penelitian Abdullah et al. (2010) yang melaporkan bahwa KcBK dan KcBO Indigofera yaitu berturut-turut sebesar $67,50 \%$ dan 60,32\%. Bulo (1985) menyatakan hasil kecernaan bahan kering dan bahan organik legum herba dan legum pohon berkisar antara 35\% sampai $63 \%$.

Kecernaan bahan kering dan bahan organik menunjukkan tren penurunan nilai kecernaan selaras 
dengan meningkatnya umur pemotongan $(\mathrm{P}<0,05)$. Menurunnya KcBK dan KcBO disebabkan oleh meningkatnya umur pemotongan sehingga terjadi perubahan komposisi kimia pada tanaman, dimana dengan semakin meningkatnya umur menyebabkan porsi dinding sel lebih tinggi dibanding isi sel. Kandungan dinding sel (selulosa dan hemiselulosa) yang tinggi akan menjadi pembatas dalam proses degradasi pakan dalam rumen. McDonald et al. (2011) menyatakan bahwa peningkatan proporsi serat pada tanaman merupakan faktor yang mempengaruhi kecernaan.

Kecernaan suatu bahan pakan akan semakin menurun dengan meningkatnya kandungan serat kasar, dalam penelitian ini keadaan tersebut terilustrasi pada menurunnya kandungan protein kasar. Kandungan serat kasar dan protein kasar bahan pakan umumnya menunjukkan hubungan yang berlawanan, dimana pada kondisi protein tinggi maka kandungan seratnya rendah dan sebaliknya. Nohong (2000) menyatakan bahwa penurunan kecernaan disebabkan peningkatan meningkatnya serak kasar dengan makin panjangnya interval pemotongan tanaman.

\section{SIMPULAN}

Berdasarkan hasil penelitian disimpulkan bahwa umur pemotongan dengan jarak potong 45 hari merupakan perlakuan pemotongan terbaik untuk legum I. zollingeriana yang ditandai dengan dihasilkannya kandungan nutrien serta tingkat kecernaan nutrien yang tinggi meskipun tingkat pertumbuhan dan produksi hijauan tidak setinggi yang dihasilkan pada umur pemotongan 60 hari serta Indigofera merupakan tanaman potensial yang dapat dikembangkan dan dimanfaatkan sebagai sumber pakan ternak andalan di Pulau Lombok.

\section{DAFTAR PUSTAKA}

Abdullah L. 2010. Herbage production and quality of shrub Indigofera treated by different concentration of foliar fertilizer. Media Peternakan. 32:169-175.

Association of Official Analytical Chemist. 2005. Official method of Analysis. 18 ${ }^{\text {th }}$ edn. The Association of Official Analytical Chemist. Washington, DC.

Bamualim AM. 2009. The dynamic of native grass resources in dry-land area of Indonesia to support beef cattle production: case study of Nusa Tenggara. In: Proceeding of International Seminar on Forage Based Feed Resources. Bandung, 3-7 Agustus 2009. Taipei (Taiwan): Food and Fertilizer Technology Centre (FFTC) ASPAC, Livestock Research Centre-COA, ROC and IRIAP. p. 142-148.

Beever, D. E., N. Offer, and N. Gill. 200o. The feeding value of grass and grass products. Publish for British Grassland soc. By Beckwell Science.

Crowder. L. V., and HR. Cheda 1982. Nutritive evaluation of grasses in the tropic. In: Tropical grassland husbandry. London (UK): Longman. p. 562 .

Crowder, L. V. and H. R. Cheda. 1982. Tropical Grassland Husbandry. Tropical Agri. Series. Longman, London. p. 562.

Givens. D. I., E. Owen, R. F. E. Oxford, and H. M. Omed. 2000. Forage evaluation in ruminant nutrition. CABI Publishing Wallingford U.K.

Herdiawan, I. 2013. Pertumbuhan tanaman pakan ternak leguminosa pohon Indigofera zollingeriana pada berbagai taraf perlakuan cekaman kekeringan. JITV. 18:258-264.

Kavanova, M. and V. Glozer. 2004. The use of internal nitrogen stores in the rhizomatous grass Calamagrostis epigejos during regrowth after defoliation. Annuals of Botany. 95 (3) : 457-463.

Kertulis, G. M. 2001. Effects of Nitrogen and Cutting Management on Root Growth and Productivity of a Kentucky Bluegrass (Poa pratensis L.) and White Clover (Trifolium repens L.) Pasture. Thesis. College of Agriculture, Forestry and Consumer Sciences at West Virginia University. McDonald, P., R. A. Edwards, J. F. D. Greenhalgh, C. A. Morgan, L. A. Sinclair, and R.G. Wilkinson. 2011. Animal Nutrition. $7^{\text {th }}$ edn. Prentice Hall, Harlow, London.

Ngo V. M., V. H. Nguyen, and M. T. Vuong. 1995. Biomass production of some leguminous shrubs and trees in Vietnam. LRRD. 7:1-5.

Nohong, B. 2000. Produktivitas dan kualitas campuran alang-alang dengan Peuraria (Peurariajavanicus Beth). Buletin Nutrisi dan Makanan Ternak 3: $33-40$.

Rahman, S. 2002. Introduksi tanaman makanan ternak di lahan perkebunan: respon beberapa jenis tanaman makanan ternak terhadap naungan dan tatalaksana pemotongan. Jurnal Ilmiah Ilmu-Ilmu Peternakan. 4 (1): 46-53.

Shehu Y., W. S. Alhassan, U. R. Pal, and C. J. C. Phillips. 2001. Yield and chemical composition response of Lablab purpureus to nitrogen, phosphorus and potassium fertilizers. Trop Grassl. 35:180-185.

Sirait J., K. Simanihuruk, and R. Hutasoit. 2009. The potency of Indigofera sp. as goat feed: production, nutritive value and palatability. In: Proceeding of International Seminar on Forage Based Feed Resources. Bandung, 3-7 Agustus 2009. Taipei (Taiwan): Food and Fertilizer Technology Centre (FFTC) ASPAC, Livestock Research Centre-COA, ROC and IRIAP. p. 4-7.

Tarigan A. 2009. Productivity and utilization of 
Indigofera sp. as goat's feed obtained from different interval and intensity of cutting. Thesis. Bogor Agricultural University. Indonesia.

Tilley, J. M. A. and R. A. Terry. 1963. A two-stage technique for the in vitro digestion of forage crop. J. British Grassl. Soc. 18: 104 - 111.

Tjelele, T. J. 2006. Dry matter production, intake and nutritive value of certain Indigofera spesies Thesis. Hatfield (South Africa): University of Pretoria.

Tong, Y. F., S. Y. Lee, and B. Morton. 2003. Effect of artificial defoliation on growth, production and leaf chemistry of the mangrove Kandelia Candel. J. Trop. Ecol. 19: 397-406.

Wilson, P. G and R. Rowe. 2008. A revision of the Indigofereae (Fabaceae) in Australia. 2. Indigofera species with trifoliolate and alternately pinnate leaves. TELOPEA J Plant Syst. 12:293-307. 